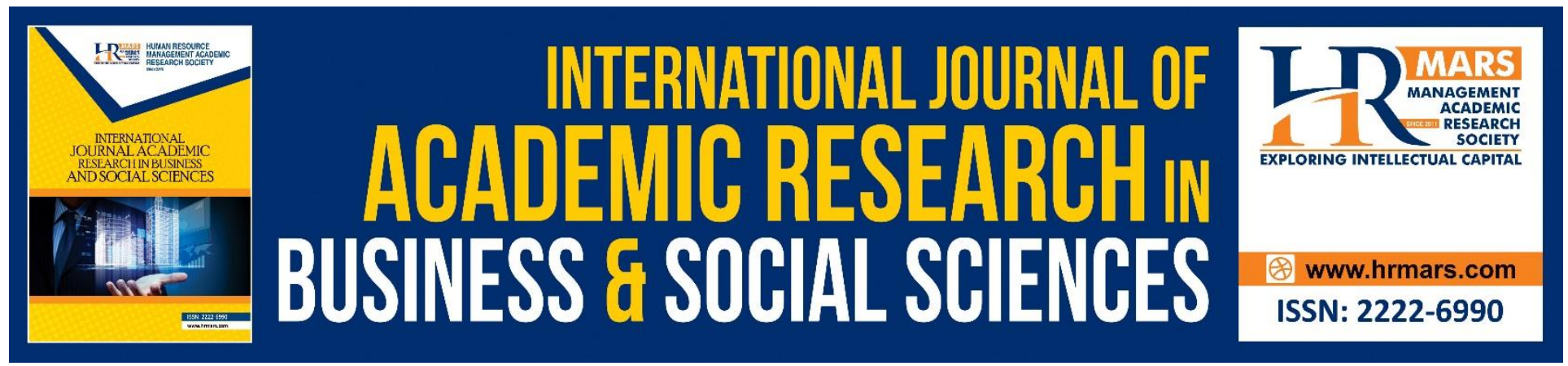

\title{
Factors Affecting the Acceptance of E-HRM in Iraq
}

\section{Azhar Naima M.}

To Link this Article: http://dx.doi.org/10.6007/IJARBSS/v9-i2/5542

DOI: $\quad 10.6007 /$ IJARBSS/v9-i2/5542

Received: 18 Jan 2019, Revised: 27 Feb 2019, Accepted: 08 March 2019

Published Online: 09 March 2019

In-Text Citation: (Azhar, 2019)

To Cite this Article: Azhar, M. N. (2019). Factors Affecting the Acceptance of E-HRM in Iraq. International Journal of Academic Research in Business and Socal Sciences, 9(2), 264-276.

\section{Copyright: (c) 2019 The Author(s)}

Published by Human Resource Management Academic Research Society (www.hrmars.com)

This article is published under the Creative Commons Attribution (CC BY 4.0) license. Anyone may reproduce, distribute, translate and create derivative works of this article (for both commercial and non-commercial purposes), subject to full attribution to the original publication and authors. The full terms of this license may be seen

at: http://creativecommons.org/licences/by/4.0/legalcode

\section{Vol. 9, No. 2, 2019, Pg. 264 - 276}

Full Terms \& Conditions of access and use can be found at http://hrmars.com/index.php/pages/detail/publication-ethics 


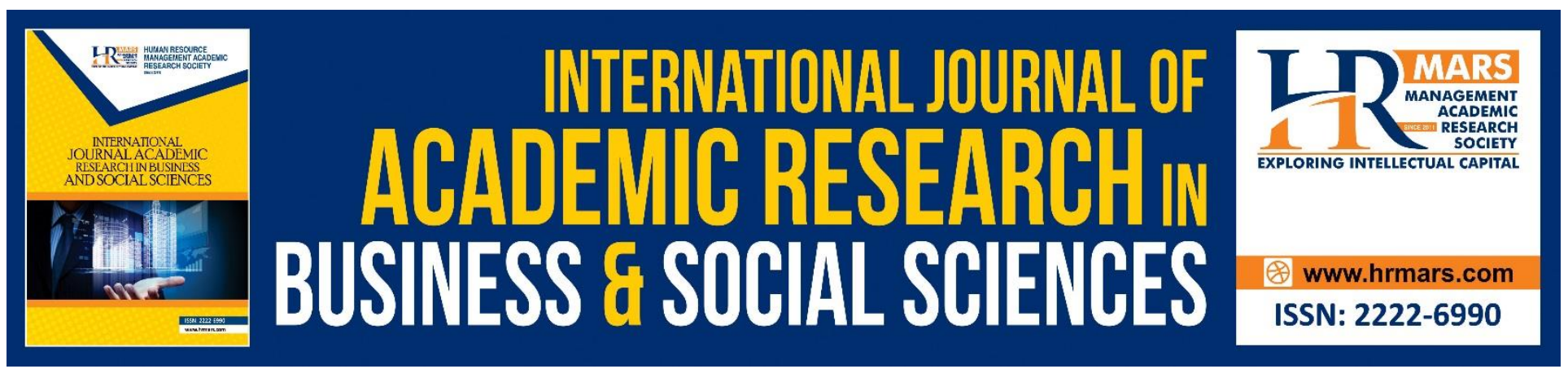

\title{
Factors Affecting the Acceptance of E-HRM in Iraq
}

\author{
Azhar Naima M. \\ College of Business Economics, Nahrain University, Iraq \\ Email: azhar.naima.m@gmail.com
}

\begin{abstract}
The purpose of the study is to investigate the factors that can impact upon the acceptance of E-HRM in the context of Iraq. As it is evident that Iraq is a developing country that are striving to boost their economy by the use of technology and enable their resources to be in the structural form that increases the feasibility to provide the adequate services to their employees and citizens. To collect the data from the respondents a questionnaire was used. The questionnaire contained two parts. Part A comprised of the questions regarding the demographic information of the respondents while part $B$ asked the questions regarding the variables included in the research framework. A random sampling technique was used to draw the sample. A sample of 332 respondents was used to analyze the data. The results of regression analysis shows that Employee's Attributes, IT Infrastructure, Compatibility, Complexity, Management Support, IT Expertise and Industry Support have significant impact on E-Human Resource Management Adoption
\end{abstract}

Keywords: E-HRM

\section{Introduction}

There is a consensus upon the efficiency and effectiveness of human resource management in the modern era of technology and modification to increases the organizational performance undoubtedly (Masum et al, 2015). Human resource management has become the strategic partner that encourages the organization to focus upon the strategic objectives that should be aligned with the organizational strategies and operations (Lawler and Mohrman, 2003). This focus has been shifted because of the advancement in the technology that has emerged the terms such as: Electronic Human Resource Management, Human Resource Information System (HRIS) and others. E-HRM is being the facets of intranet based human resource management, Virtual human resource management; website based human resource management and information system based upon the human resource management.

Electronic human resource management is being discussed such as the information system that includes the different applications of the human resource like; demand and supply of the human resource, planning for placing the candidate according to their capabilities, employee's data, hiring 
and selecting, relations with the employees, performance appraisal and others (Masum et al, 2013). The effectiveness of E-HRM has enabled the organizations to increases the efficiency of accessing the information, effective decision making and becoming a part of the strategic alliance with the business partners (Rodriguez and Ventura, 2003). In the organization few factors impact upon the management in order to execute the strategy of E-HRM. The literatures on the factors that are effecting the successful adoption of E-HRM are having lack of information particularly in the developing countries such as Iraq. The use of human resource management is at the initial stage and the addition of E-HRM is considered as the innovative stage in the country. It is evident from the previous study that most of the organization are reluctant to implement the E-HRM because they consider it is a cost increasing activity, lack of experience and professionalism, training element is lacking and top management is not interested therefore; they are not able to accept the benefits of E-HRM to make the organizational successful (Jahan, 2014; Masum et al, 2013).

The researchers suggest that there are several benefits of accepting the E-HRM that are higher than the limitation of the system. It is suggested that organizations in the developing economy must focus upon the implementation of E-HRM because it will increase the interaction and communication of the management with the employees along with this they will be able to use the human resource management practices successfully in the organization (Troshani et al 2011). Employees will be benefited through the roles and providing the education and training on the job as well (Delmore and Arcand, 2010). The purpose of the study is to investigate the factors that can impact upon the acceptance of E-HRM in the context of Iraq. As it is evident that Iraq is a developing country that are striving to boost their economy by the use of technology and enable their resources to be in the structural form that increases the feasibility to provide the adequate services to their employees and citizens.

\section{Literature Review}

Human resource has been changed since it was introduced because of the requirement of the current market practices therefore; today it is highly acceptable and advanced field as compared to the past. The human resource operations are not limited to hiring or selecting the individual but also it is beyond the organizational process where strategic planning and technology interface is the main feature of the new face of human resource management (Tremblay et al, 2008; Ulrich, 1996). The aim of the study is to focus upon the acceptance of E-HRM particularly and identify the factors that affect the organization or individual in the case of adoption. E-HRM illustrates by the researchers such as: It is a process of executing the human resource planning, practices and strategies in the organization with the help of technology that can be through intranet or internet based (Ruel et al, 2004); in the current era context; it is more of using the technology in the form of information system that is owned by human resource to perform their activities efficiently (Strohmeier, 2007).

E-HRM is being used by the organization in order to meet the daily routine activities and long term objectives as well which include the recruitment, selection, training, development, performance appraisal and others (Thite and Kavangh, 2009); moreover it can be used to manage the individual or employee whole career or lifecycle through it. E-HRM is not only focus upon the human resource activities but also it enables to plan and become the strategic partner for the organization who are taking part in the development of strategic planning and goals setting of the organization 
(Martinsons, 1994). The information system of human resource has enabled the organization to provide the facility to employees and managers adequately through the self learning system. In the current era; human resource management has been improved and the mindset about the human resource has been shifted from the labor or employee centric to technological centric (Florkowski and Olivias-Lujan, 2006); now organizations are become technologically advanced that provided solution to the employees through self administered software rather than consulting with the human resource department. In the literature there are several studies are being conducted in the developing countries regarding the success of E-HRM (Ruta, 2005).

In the literature it is suggested that organization can be benefited through the E-HRM such as cost cutting, quality services of $\mathrm{HR}$, focusing on strategic objectives and adopting attitude towards accepting the change of the environment (Ruel et al, 2004). The most of the researchers have identified the two major advantages of E-HRM for the process of human resources that are performance quality and cost cutting (Buckley et al, 2004) along with this pursuing the organization strategic objectives through their daily routine operations (Gardner et al, 2003; Snell et al, 2003). There are different researchers conducted their researchers to describe or illustrate about the successful adoption of E-HRM but lack of information or research is being done on the factors that are affecting the successful acceptance of E-HRM in the developing country (Sarode et al, 2010)

Adopting new technology is a highly concern issue for the researcher and therefore; researchers have identified different factors. This study is about to analyze the factors that impact upon the acceptance of E-HRM. There are four different levels that are going to be considered in the study such as: individual, organizational, technological and environmental level. It is evident that information system should be user friendly that enable the human resource system in terms of technology enables the organization to become successful. Technology acceptance model was develop by the Richter et al, (2013) that was based upon the factors such as User's perception, behavior, motivation, intention and adoption of technology to use the information system adequately.

It enables the users to identify their behavior and communication with their ability to interact with the technology which makes the organizational system successful or make it fail to implement (Delorme and Arcand, 2010; Troshani et al, 2011). In the study it is suggested that top management behavior towards the acceptance and adoption of technology matter in high regard if they likely to have the adoptive behavior then it will be feasible for the organizations to implement the technological features in the system or processes of the organization especially in the small and medium size enterprises (Thong, 1999).

Previous studies suggested that information technology knowledge to the individual and their colleague urge them to adopt or accept the technological transformation towards the E-HRM (Ruel et al, 2004; Voermans and Van Veldhoven, 2007). Organizational factors enable the researcher to identify some factors that impact upon the acceptance of E-HRM. The study suggested that organizational size, organizational infrastructure and capability of the employees are the main factors that urge the organization to adopt or accept the technology (Strohmeier, 2009; Troshani et al, 2011). In that case of technology adoption the management support and their behavior is highly important (Teo et al, 2007). The important of skilled employees are highly supportive towards the management initiative regarding the adoption of the technology. There are number of researchers analyzed the contribution of the organizational management and their approach towards the acceptance of the 
technology is the important aspect in the organization to execute the intervention of E-HRM (Altarawneh and Al Shqairat, 2010; Teo et al, 2007; Troshani et al, 2011).

Study suggest that for the adoption or acceptance of technology for the organization it is highly important that employees should be familiar with the technology and accept it which will be the major condition for the organization to implement E-HRM in the organization (Teo et al, 2007). The limitation to the acceptance of the technology is that if the employee or the end user is not having any knowledge or information of using the technology then it will not be feasible for the organization to make a successful implementation of the E-HRM in the system. From the organization perspective it is necessary that management should support the financially towards the technology adoption and implement the E-HRM in the organization then it will be effective (Ngai and Wat, 2006; Parsa, 2007; Reddick, 2009; Masum, 2015). Technological aspect suggests that technology itself urge the organization to get benefited from it (Hoon et al, 2007). Those that adopt the technology classify the term as the potential benefits and potential hurdles. As far as the potential benefits are concern it is being suggested that it increases the quality of productivity, performance and control in the organization (Oliveira and Martins, 2010). As far as the hurdles are concern such as: the lack of knowledge to handle the technology, lack of infrastructure to support the technological implementation in the system or processes, lack of trained or technology literature individuals which makes the adoption as a failure for the organization (Rogers, 2003). The undertaking the technology is highly difficult when the mentioned issues exist and end user is not producing the desired results through it (Rogers, 2003). The study was conducted in the Singapore and suggested that at the manager's level harmonization with the technology and utilizing it effectively are the main drivers for the technology to become successful especially in the case of E-HRM (Teo et al, 2007). It is also suggested that the readiness of the organization towards the adoption of the technology is the major force to accept technology quickly. Employee knowledge over technology and organizational support to develop the technology infrastructure is the best example to adopt or accept the technology adequately (Oliveira and Martins, 2010).

Environmental factors that suggests the organizational existence in the locality where it is situated, industrial zone exist, government subsidies, government regulations and established structure for the organization to flourish their business (Oliveira and Martins, 2010; Troshani et al, 2011). Industry pressure is denoted as the environmental factor that also impact upon the organizational strategy to adopt the technology (Kittipong, 2009). Industry pressure to an extent develops pressure on the organization to adopt the changes of the market or environment such as gaining the competitive edge over other and making their operations successful effectively in the industry. It is evident that majority of organization compel to adopt the technology due to the industry pressure in order to meet their strategies opportunities like; cost cutting, managing the human resources effectively (Teo et al, 2007; Masum, 2015). It is suggested in the study of Thong, (1999) that organization cannot become successful if they are not able to manage their human resource effectively. In the result of this; large number of organization have adopted the technology in the form of E-HRM and successfully implemented to meet their ultimate strategic objectives. So, it can be suggested that competition can be considered as the environmental factor that urge the organization to accept the E-HRM to implement and get the benefits of it. 


\section{Conceptual Framework}



\section{Methodology}

The study seeks to investigate the factors affecting adoption of E-HRM. The study in quantitative in nature as it seeks to empirically test the relationships using a close ended questionnaire.

\section{Questionnaire Design}

As the study was aimed to examine the factors affecting adoption of E-HRM. It needs to be collect the data from a survey method as the survey method is appropriate for this type of study. To collect the data from the respondents a questionnaire was used. The questionnaire contained two parts. Part A comprised of the questions regarding the demographic information of the respondents while part B asked the questions regarding the variables included in the research framework. All questions were designed using five-point likert scale. All the construct used in the research framework was measured using multi-items.

\section{Sample size and Technique}

To take the views from the respondents who are the representative of the population a sample has to be determined for the data collection. Hence it has to be made sure the representativeness of the sample. In this regard random sampling technique is appropriate. Hence random sampling technique 
was used to draw the sample. A sample of 332 respondents was used to analyze the data. Initially the questionnaire was distributed among 450 individuals out of them 355 questionnaires were returned. However 23 of them were left partially or fully unfilled. Hence the remaining 332 questionnaires were found to be useful.

\section{Data Analysis}

The data was initially put in the software using a predefined codebook. The data was first cleaned and preliminary analysis were done. As data cleaning is vital in the quantitative times for study as it should be free from the entry errors, missing values, ouliers etc. The preliminary analysis include missing values treatment, normality and outliers etc. The main analysis then included demographic analysis, descriptive statistics, reliability, correlation and regression. SPSS 22 was employed to examine the data. For testing the relationships and impacts it is appropriate to apply ordinary least square method of regression which provides us the coefficients for the individual independent variables along with their t-statistics and $p$-values which help us determine the significance of the relationships. Hence the study applied the multiple regression analysis using ordinary least square method to test the hypotheses lead by the research objectives.

\section{Results and Findings}

The results of data analysis are presented in the following section.

\section{Demographic Analysis}

\section{Gender}

\begin{tabular}{|ll|l|l|l|l|}
\hline & & Frequency & Percent & Valid Percent & Cumulative Percent \\
\hline Gender & Male & 235 & 70.8 & 70.8 & 70.8 \\
& Female & 97 & 29.2 & 29.2 & 100.0 \\
& Total & 332 & 100.0 & 100.0 & \\
\hline Age & $20-25$ & 113 & 34.0 & 34.0 & 34.0 \\
& $26-35$ & 167 & 50.3 & 50.3 & 84.3 \\
& $36-45$ & 39 & 11.7 & 11.7 & 96.1 \\
& Above 45 & 13 & 3.9 & 3.9 & 100.0 \\
& Total & 332 & 100.0 & 100.0 & \\
\hline Education & Secondary & 1 & .3 & .3 & .3 \\
& Diploma & 66 & 19.9 & 19.9 & 20.2 \\
& Bachelors & 225 & 67.8 & 67.8 & 88.0 \\
Masters & 36 & 10.8 & 10.8 & 98.8 \\
PhD. & 4 & 1.2 & 1.2 & 100.0 \\
Total & 332 & 100.0 & 100.0 & \\
\hline
\end{tabular}

The demography of the respondents is presented in the above table. The table shows that out of total 332 respondents 235 were male and 97 were females. The age of the respondents was between 26 
and 25 for around $50 \%$ of the respondents while $34 \%$ were aged between 20 and $25.11 \%$ were 36 45 years old while remaining $4 \%$ were above the age of 45 . As far as the education of the respondents is concerned only 1 was having the secondary education, 66 were holding diploma, 225 were bachelors and 36 were masters. However only 4 respondents were holding a PhD degree.

Descriptive Statistics

\begin{tabular}{|l|l|l|l|l|l|}
\hline & $\mathrm{N}$ & Min & Max & Mean & Std. Deviation \\
\hline E-Human Resource Management & 332 & 1.00 & 5.00 & 3.2244 & 1.08447 \\
\hline Employees' Attributes & 332 & 1.00 & 5.00 & 3.3268 & 1.14529 \\
\hline IT Infrastructure & 332 & 1.00 & 5.00 & 3.1227 & 1.09111 \\
\hline Compatibility & 331 & 1.00 & 5.00 & 3.0634 & .86566 \\
\hline Complexity & 332 & 1.00 & 5.00 & 2.9390 & .94538 \\
\hline IT Expertise & 332 & 1.75 & 4.25 & 2.7274 & .61010 \\
\hline Industry Pressure & 332 & 1.00 & 5.00 & 3.2372 & 1.03581 \\
\hline Management Support & 332 & 1.00 & 5.00 & 3.6468 & 1.09985 \\
\hline
\end{tabular}

The above table shows the descriptive statistics of the variables included in the research framework. The minimum and maximum value of the all the variables were 1 and 5 respectively except the variable IT expertise has the maximum value of 4.25. The mean values ranged between 2.72 to 3.64 while the standard deviation ranged between 0.64 and 1.14. Moreover the total number of observation of 332 showed the sample size was 332 .

\section{Reliability}

The reliability of the constructs in shown in the table below.

\begin{tabular}{|l|l|l|}
\hline Constructs & No of Items & Cronbach's Alpha \\
\hline E-Human Resource Management (EHRM) & 04 & 0.848 \\
\hline Employees' Attributes (EA) & 04 & 0.879 \\
\hline IT Infrastructure (ITI) & 04 & 0.841 \\
\hline Compatibility (COM) & 04 & 0.851 \\
\hline Complexity (COMPL) & 04 & 0.795 \\
\hline IT Expertise (IE) & 04 & 0.719 \\
\hline Industry Pressure (IP) & 04 & 0.819 \\
\hline Management Support (MS) & 04 & 0.830 \\
\hline
\end{tabular}

The above table of the reliability shows the values of Cronbach's Alpha for each of the constructs. The values of alpha were found to be between 0.719 and 0.879 . Hence all the values were found to be above the threshold value of 0.7 . Which means the requirement for the construct reliability was met. 


\section{Correlation Analysis}

\begin{tabular}{|l|l|l|l|l|l|l|l|l|}
\hline & EHRM & EA & ITI & COM & COMPL & IE & IP & MS \\
\hline EHRM & 1 & & & & & & & \\
\hline EA & $.359^{* *}$ & 1 & & & & & & \\
\hline ITI & $.301^{* *}$ & $.274^{* *}$ & 1 & & & & & \\
\hline COM & $.245^{* *}$ & .060 & -.013 & 1 & & & & \\
\hline COMPL & $.146^{* *}$ & $-.240^{* *}$ & -.064 & .014 & 1 & & & \\
\hline IE & $.020^{*}$ & $-.160^{* *}$ & .019 & -.038 & $.155^{* *}$ & 1 & & \\
\hline IP & $.028^{*}$ & $.219^{* *}$ & $-.176^{* *}$ & -.034 & $-.362^{* *}$ & $-.429^{* *}$ & 1 & \\
\hline MS & $.308^{* *}$ & -.005 & $.202^{* *}$ & $.111^{*}$ & $.246^{* *}$ & -.049 & $-.192^{* *}$ & 1 \\
\hline
\end{tabular}

* Correlation is significant at the 0.05 level (2-tailed).

**. Correlation is significant at the 0.01 level (2-tailed).

The above table of correlation shows that all independent variables (Employee Attributes, IT Infrastructure, Compatibility, Complexity and Management Support) were significantly correlated with the dependent variable (E- Human Resource Management) as the $p$-values for all the correlations were below 0.05. Moreover the correlation among the independent variables ranged from 0.020 to 0.359 which shows the low values of correlation. The correlation value of 0.9 and above between independent variables shows the high probability of multicollinearity between the two independent variables. However this issue was not found in the current data.

\section{Regression}

To test the hypotheses of the study regression analysis was performed the result of the regression analysis is shown in the table below.

\begin{tabular}{|c|c|c|c|c|c|}
\hline & \multicolumn{2}{|c|}{$\begin{array}{l}\text { Unstandardized } \\
\text { Coefficients }\end{array}$} & \multirow{2}{*}{$\begin{array}{l}\text { Standardized } \\
\text { Coefficients } \\
\text { Beta }\end{array}$} & \multirow[b]{2}{*}{$\mathrm{t}$} & \multirow[b]{2}{*}{ Sig. } \\
\hline & B & Std. Error & & & \\
\hline Employees' Attributes & .301 & .047 & .318 & 6.375 & .000 \\
\hline IT Infrastructure & .217 & .050 & .217 & 4.365 & .000 \\
\hline Compatibility & .264 & .057 & 211 & 4.625 & .000 \\
\hline Complexity & .252 & .058 & .220 & 4.335 & .000 \\
\hline Management Support & .227 & .048 & .230 & 4.734 & .000 \\
\hline IT Expertise & .226 & .090 & .127 & 2.510 & .013 \\
\hline Industry Support & .189 & .058 & .181 & 3.251 & .001 \\
\hline
\end{tabular}

The above table of the regression analysis shows that Employee's Attributes, IT Infrastructure, Compatibility, Complexity, Management Support, IT Expertise and Industry Support have significant impact on E-Human Resource Management Adoption as the p-values were below 0.05. Moreover all 
the beta coefficients were having a positive sign which shows that all relationships were positive. The summary of the hypotheses is presented in the table below.

\section{Summary of Hypotheses}

\begin{tabular}{|l|l|l|}
\hline Hypotheses & P-values & Results \\
\hline There is a positive impact of Employees' Attribute on E-HRM Adoption. & 0.000 & Supported \\
\hline There is a positive impact of IT Infrastructure on E-HRM Adoption. & 0.000 & Supported \\
\hline There is a positive impact of Compatibility on E-HRM Adoption. & 0.000 & Supported \\
\hline There is a positive impact of Complexity on E-HRM Adoption. & 0.000 & Supported \\
\hline There is a positive impact of Management Support on E-HRM Adoption. & 0.000 & Supported \\
\hline There is a positive impact of IT Expertise on E-HRM Adoption. & 0.013 & Supported \\
\hline There is a positive impact of Industry Support on E-HRM Adoption. & 0.001 & Supported \\
\hline
\end{tabular}

The above table shows that all the hypotheses were found to be supported hence it can be said that Employee's Attributes, IT Infrastructure, Compatibility, Complexity, Management Support, IT Expertise and Industry Support have significant impact on E-Human Resource Management Adoption.

\section{Discussion and Conclusion}

The study was aimed to examine the relationship of (Employee's Attributes, IT Infrastructure, Compatibility, Complexity, Management Support, IT Expertise and Industry Support) with E-Human Resource Management Adoption. The results showed all the relationships to be significantly positive. The aim of the study is to focus upon the acceptance of E-HRM particularly and identify the factors that affect the organization or individual in the case of adoption. E-HRM illustrates by the researchers such as: It is a process of executing the human resource planning, practices and strategies in the organization with the help of technology that can be through intranet or internet based (Ruel et al, 2004); in the current era context; it is more of using the technology in the form of information system that is owned by human resource to perform their activities efficiently (Strohmeier, 2007).

\section{Employee attributes, IT infrastructure, compatibility and E-HRM acceptance}

The information system of human resource has enabled the organization to provide the facility to employees and managers adequately through the self-learning system. In the current era; human resource management has been improved and the mindset about the human resource has been shifted from the labor or employee centric to technological centric (Florkowski and Olivias-Lujan, 2006). The study suggested that organizational size, organizational infrastructure and capability of the employees are the main factors that urge the organization to adopt or accept the technology (Strohmeier, 2009; Troshani et al, 2011).

\section{Complexity, IT expertise, Industry pressure, management support and E-HRM Acceptance}

Previous studies suggested that information technology knowledge to the individual and their colleague urge them to adopt or accept the technological transformation towards the E-HRM (Ruel et al, 2004; Voermans and Van Veldhoven, 2007). 
Industry pressure is denoted as the environmental factor that also impact upon the organizational strategy to adopt the technology (Kittipong, 2009). Industry pressure to an extent develops pressure on the organization to adopt the changes of the market or environment such as gaining the competitive edge over other and making their operations successful effectively in the industry. It is evident that majority of organization compel to adopt the technology due to the industry pressure in order to meet their strategies opportunities like; cost cutting, managing the human resources effectively (Teo et al, 2007; Masum, 2015). All the results of the hypotheses were found to be supported and in line with the literature

In that case of technology adoption the management support and their behavior is highly important (Teo et al, 2007). The important of skilled employees are highly supportive towards the management initiative regarding the adoption of the technology. It enables the users to identify their behavior and communication with their ability to interact with the technology which makes the organizational system successful or make it fail to implement (Delorme and Arcand, 2010; Troshani et al, 2011). In the study it is suggested that top management behavior towards the acceptance and adoption of technology matter in high regard if they likely to have the adoptive behavior then it will be feasible for the organizations to implement the technological features in the system or processes of the organization especially in the small and medium size enterprises (Thong, 1999).

\section{Limitation and Future Research}

The above study is limited to the general factors that affect the E-HRM adoption however there are certain models such as TAM technology acceptance model which define the adoption of technology hence in future researchers can apply the Technology acceptance model to understand the phenomena along with the variables indicated in the current study. Moreover the sample of the study was limited to only one country. In future more countries can be involved and a comparative study can be conducted. This study was based on a quantitative design so in future mixed method research can also be conducted to have in-depth knowledge of the phenomena.

\section{References}

Altarawneh, I., \& Al-Shqairat, Z. (2010). Human resource information systems in Jordanian universities. International Journal of Business and Management, 5(10), 113-123.

Delorme, M., \& Arcand, M. (2010). HRIS implementation and deployment: a conceptual framework of the new roles, responsibilities and competences for HR professionals. International journal of Business information systems, 5(2), 148-161. http://dx.doi.org/10.1504/IJBIS.2010.030626

Florkowski G. And Olivias-Lujan M. (2006). The diffusion of human resource informationtechnology innovations in US and non-US firms. Personnel Review, 35 (6), 684-710.

Gardner, S., Lepak D. and Bartel K. (2003). Virtual HR: The impact of information technology on the human resource professional. Journal of Vocational Behavior, 63 (2), 159-179.

Jahan, S. (2014). Human Resources Information System (HRIS): A Theoretical Perspective. Journal of Human Resource and Sustainability Studies, 2, 33-39. http://dx.doi.org/10.4236/jhrss.2014.22004

Kittipong, S. (2009). The adoption of techno-relationship innovations. Marketing Intelligent and Professionals, 27(3), 380-412. 
Lawler, E. E., \& Mohrman, S. A. (2003). HR as a strategic partner: What does it take to make it happen? Human Resource Planning, 26(3), 15-29.

Martinsons, M G (1994), "Benchmarking Human Resource Information Systems in Canada and Hong Kong", Information \& Management.

Masum, A. K. M., Azad, M. A. K., \& Beh, L.-S. (2015). The role of human resource management practices in bank performance. Total Quality Management \& Business Excellence, 1-16. http://dx.doi.org/10.1080/ 14783363.2014.1002762

Masum, A. K. M., Bhuiyan, F., \& Kabir, R. (2013). HRIS Practices in Universities: An Exploratory Study on the Private Universities In Bangladesh. Global Journal of Human-Social Science Research, 13(7), 25-29.

Ngai, E., \& Wat, F. (2006). Human resource information systems: a review and empirical analysis. Personnel Review, 35(3), 297-314. http://dx.doi.org/10.1108/00483480610656702

Oliveira, T., \& Martins, M. F. (2010). Understanding e-business adoption across industries in European countries. Industrial Management \& Data Systems, 110(9), 1337-1354. http://dx.doi.org/10.1108/02635571011087 428

Parsa, H. (2007). Critical Determinants in Implementing HRIS in Restaurant Chains. Advances in Hospitality and Leisure, (3), 69-86.

Reddick, C. G. (2009). Human Resources Information Systems in Texas City Governments: Scope and Perception of its Effectiveness. Public Personnel Management, 38(4), 19-34. http://dx.doi.org/10.1177/009102600903800402

Richter, A., Stocker, A., Müller, S., \& Avram, G. (2013). Knowledge management goals revisited: A cross-sectional analysis of social software adoption in corporate environments. VINE, 43(2), 132-148. http://dx.doi.org/10.1108/03055721311329927

Rodríguez, J. M., \& Ventura, J. (2003). Human resource management systems and organizational performance: an analysis of the Spanish manufacturing industry. International Journal of Human Resource Management, 14(7), 1206-1226. http://dx.doi.org/10.1080/0958519032000114273

Rogers, E. M. (2003). Diffusion of Innovation (4th ed.). New York: The Free Press.

Ruel, H., Bondarouk, T., \& Looise, J. (2004). EHRM: Innovation or irritation. An explorative empirical study in five large companies on webbased HRM. Management Revue, 15, 364-380

Ruël, H., Bondarouk, T., \& Looise, J. K. (2004). E-HRM: innovation or irritation. An explorative empirical study in five large companies on web-based HRM. Management Revue, 15(3), 364-380.

Ruta C. (2005). The application of change management theory to HR portal implementation in subsidiaries of multinational corporations. Human Resource Management, 44 (1), 35-53.

Sarode, A. P. (2012), "E-HRM: Transforming HR through Technology", AMS International E-Journal of Ongoing Research in Management and IT, pp. 1-10.

Snell S., Stueber D.and Lepak D. (2002). Virtual HR departments: getting out of the middle. In: R. Henneman and D. Greenberger (Eds.), Human Resource Management in Vitual Organizations, Greenwich: Information Age Publishing.

Strohmeier, S. (2007). Research in e-HRM: Review and implications. Human Resource Management Review, 17(1), 19-37. 
Strohmeier, S. (2009). Concepts of e-HRM consequences: a categorisation, review and suggestion. The International Journal of Human Resource Management, 20(3), 528-543. http://dx.doi.org/10.1080/095851 90802707292

Teo, T. S., Lim, G. S., \& Fedric, S. A. (2007). The adoption and diffusion of human resources information systems in Singapore. Asia Pacific Journal of Human Resources, 45(1), 44-62. http://dx.doi.org/10.1177/ 1038411107075402

Thite, M. and Kavanagh, M. (2009). Evolution of human resource management and human resource information systems: the role of information technology. In: M. Kavanagh and M. Thite, Human Resource Information Systems: Basics, Applications and Future Directions. Thousand Oaks: Sage Thong, J. Y. (1999). An integrated model of information systems adoption in small businesses. Journal of management information systems, 15(4), 187-214.

Tremblay M., Patry M. And Lanoie, P. (2008). Human resource outsourcing in Canadian organizations: An empirical analysis of the role of organizational characteristics, transaction costs and risks. International Journal of Human Resource Management, 19

Ulrich D. (1996). Human Resource Champions. Boston: Harvard Business Review.

Voermans, M., \& van Veldhoven, M. (2007). Attitude towards E-HRM: an empirical study at Philips. Personnel Review, 36(6), 887-902. http://dx.doi.org/10.1108/00483480710822418 